\title{
Demografi, Respon Terapi dan Survival rate Pasien Kanker Serviks Stadium III-IVA yang Mendapat Kemoterapi Dilanjutkan Radioterapi
}

\author{
Yuski Amin', Pungky Mulawardhana', Dyah Erawati \\ 'Departemen Obstetri Ginekologi, Fakultas Kedokteran Universitas Airlangga, RSUD Dr. Soetomo, Surabaya \\ ${ }^{2}$ Instalasi Radioterapi, Fakultas Kedokteran Universitas Airlangga, RSUD Dr. Soetomo, Surabaya
}

\section{ABSTRAK}

Tujuan: Mengetahui demografi pasien kanker serviks III-IVa, respon terapi dan survival rate pasien kanker serviks stadium IIIIVA yang mendapat kemoterapi dilanjutkan radioterapi di RSUD Dr. Soetomo Surabaya tahun 2011-2013.

Bahan dan Metode: Penelitian ini adalah penelitian deskriptif rektrospektif dengan menggunakan rekam medis Poli Onkologi Kandungan dan SMF/Instalasi Radioterapi RSUD Dr.Soetomo. Subyek penelitian adalah pasien kanker serviks III-IVA yang mendapat kemoterapi dilanjutkan radioterapi mulai Januari 2011 sampai Desember 2013. Analisis statistika pada penelitian ini menggunakan analisis deskriptif dan analisis survival menggunakan metode Kaplan Meier.

Hasil: Selama tahun 2011-2013 didapatkan kunjungan pasien baru kanker serviks III-IVA sebanyak 648 pasien. Jumlah pasien kanker serviks IIIA sebanyak 48 kasus, stadium IIIB sebanyak 594 kasus dan stadium IVA sebanyak 6 kasus. Jumlah pasien kanker serviks III-IVA yang mendapat kemoterapi dilanjutkan radioterapi selama tahun 2011-2013 sebanyak 77 pasien. Pasien kanker serviks stadium IIIA sebanyak 8 pasien, stadium IIIB sebanyak 69 pasien. Tidak ada pasien kanker serviks stadium IVA yang mendapat kemoterapi dilanjutkan radioterapi. Respon terapi komplet sebesar $88,3 \%$ dan respon terapi inkomplet sebesar $11,7 \%$. Analisis survival dengan metode Kaplan-Meier didapatkan 2-YSR dan 3-YSR kanker serviks stadium IIIA sebesar $86 \%$ dan $34 \%$. Pada stadium IIIB didapatkan 2-YSR dan 3-YSR sebesar $47 \%$ dan 25\%.Median survival pada semua kelompok pada penelitian ini adalah 25 bulan.

Simpulan: Jumlah pasien kanker serviks III-IVA yang mendapat kemoterapi dilanjutkan radioterapi selama tahun 2011-2013 sebanyak 77 pasien. Respon terapi komplet pasca radioterapi sebesar $88,3 \%$ dan respon terapi inkomplet sebesar 11,7\%. Hasil analisis survival didapatkan 2-YSR dan 3-YSR kanker serviks stadium IIIA sebesar $86 \%$ dan 34\%. Pada stadium IIIB didapatkan 2-YSR dan 3-YSR sebesar $47 \%$ dan $25 \%$.

Kata Kunci: kanker serviks, kemoterapi, radioterapi, respon terapi, survival

\begin{abstract}
Objectives: To determine patient demographics III-IVa cervical cancer, therapy response and survival rate of cancer patients with stage III-IVA cervical receiving chemotherapy followed radiotherapy at the Hospital Dr. Soetomo 2011-2013.

Materials and Methods: This study was a descriptive study using on medical records rektrospektif at Oncology Gynecology Clinic and Radiotherapy Installation, Dr. Soetomo Hospital. Subjects were patients with III-IVA cervical cancer who received chemotherapy followed radiotherapy from January 2011 to December 2013. Statistical analysis of this research using descriptive analysis and survival analysis using the Kaplan Meier method.

Results: During the years 2011-2013 obtained a new patient visit III-IVA cervical cancer as many as 648 patients. IIIA number of cervical cancer patients were 48 cases, as many as 594 cases of stage IIIB and stage IVA as much as 6 cases. The number of cervical cancer patients III-IVA who received chemotherapy followed radiotherapy during the years 2011-2013 as many as 77 patients. Cervical cancer patients as many as eight patients with stage IIIA, IIIB as many as 69 patients. There is no stage IVA cervical cancer patients who received chemotherapy followed radiotherapy. Complete therapeutic response of $88.3 \%$ and an incomplete response to therapy was $11.7 \%$. Analysis of survival by Kaplan-Meier method obtained 2-and 3-YSR YSR cervical cancer stage IIIA by $86 \%$ and $34 \%$. In stage IIIB obtained 2 -and 3 -YSR YSR by $47 \%$ and $25 \%$.Median survival in all groups in this study was 25 months.

Conclusions: The number of patients III-IVA cervical cancer who received chemotherapy followed radiotherapy during the years 2011-2013 as many as 77 patients. Complete response to therapy after radiotherapy for $88.3 \%$ and incomplete response to therapy was $11.7 \%$. Survival analysis results obtained 2-and 3-YSR YSR cervical cancer stage IIIA by $86 \%$ and $34 \%$. In stage IIIB obtained 2 -and 3-YSR YSR by $47 \%$ and $25 \%$.
\end{abstract}

Keywords: cervical cancer, chemotherapy, radiotherapy, therapy response, survival

Correspondence: Yuski Amin, Departemen Obstetri Ginekologi, Fakultas Kedokteran Universitas Airlangga-RSUD Dr. Soetomo, Surabaya, Jawa Timur, Indonesia, Telp: \pm 62811377110 , email: yuski_amin@yahoo.com

\section{PENDAHULUAN}

Kanker di Indonesia menempati urutan kelima tertinggi penyebab kematian, disebabkan meningkatnya jumlah pasien kanker dari tahun ke tahun dan peningkatan angka harapan hidup wanita Indonesia. Lebih dari $40 \%$ keganasan pada wanita Indonesia merupakan kanker ginekologi. ${ }^{1}$ Di Indonesia pada tahun 2012 dilaporkan 20.928 kasus baru kanker serviks dan angka kematian terkait kanker serviks sebanyak 9.498 kasus. $^{2}$ Menurut FIGO 2000, terapi kanker serviks terdiri dari beberapa modalitas terapi. yaitu pembedahan, radiasi, kemoterapi, dan kombinasi dari modalitas terapi tersebut. Pilihan terapi tergantung dari stadium klinik, dan hal ini mempengaruhi kesintasan dan kemungkinan kontrol lokal dan lokoregional Radioterapi merupakan salah satu modalitas terapi pada kanker ginekologi. Di bidang kanker ginekologi, terapi radiasi banyak digunakan 
sebagai modalitas terapi kanker serviks, kanker vulva/vagina dan kanker endometrium. Radioterapi merupakan terapi utama pada kanker serviks stadium lanjut (locally advanced).,

Akan tetapi karena keterbatasan sarana radioterapi di RSUD Dr.Soetomo, pasien kanker serviks stadium lanjut mendapat kemoterapi dan menunggu terapi definitif radioterapi. Sehingga terapi kanker serviks stadium lanjut di RSUD Dr.Soetomo sedikit berbeda dengan rekomendasi FIGO.

Penelitian di RSUD Dr.Soetomo tahun 2010 melaporkan jumlah pasien kanker serviks stadium lanjut yang mendapat radioterapi sebesar 176 pasien $(26,5 \%)$ dari 663 kasus. $^{5}$ Sebuah studi oleh Takashi di Jepang membahas tentang luaran 1148 pasien kanker serviks stadium IB, II, III yang mendapat terapi radiasi antara tahun 1968 sampai 1986. Penelitian tersebut melaporkan 10 year survival rates masing-masing stadium adalah $74 \%$ pada stadium IB, $52 \%$ pada stadium II dan $42 \%$ pada pasien kanker serviks stadium III. ${ }^{6}$

Di RSUD Dr.Soetomo banyak pasien kanker serviks mendapat terapi radiasi. Pada penelitian ini dilakukan pengamatan tentang data epidemiologi pasien kanker serviks III-IVA serta juga pengamatan terhadap luaran radioterapi dan survival pada pasien kanker serviks stadium III-IVA yang mendapat kemoterapi dilanjutkan radioterapi.

\section{BAHAN DAN METODE}

Penelitian dilakukan secara retrospektif menggunakan data sekunder dari rekam medis Poli Onkologi Kandungan, rekam medis SMF/Instalasi Radioterapi dan rekam medis rawat inap Ruang Kandungan RSUD Dr.Soetomo Surabaya. Seluruh pasien kanker serviks III-IVA yang mendapat kemoterapi dan dilanjutkan radioterapi di RSUD dr. Soetomo selama tahun 2011 sampai 2013 yang termasuk dalam kriteria inklusi dan ekslusi dimasukkan kedalam penelitian ini. Kriteria inklusi penelitian ini yaitu pasien kanker serviks uteri III-IVA yang mendapat kemoterapi dilanjutkan radioterapi dan telah dilakukan evaluasi pasca radioterapi.

Pengumpulan data dilakukan selama bulan Desember 2014 sampai dengan bulan April 2015. Dilakukan pengumpulan data mengenai karakteristik usia, kondisi serviks serta evaluasi stadium kanker serviks oleh tim ginekologi onkologi, jenis histopatologi, laboratorium (hemoglobin, BUN, kreatinin), jenis dan jumlah radiasi yang didapatkan, tanggal evaluasi pasca radioterapi, evaluasi respon terapi pasca radioterapi oleh tim ginekologi onkologi serta hasil pemeriksaan pap smear pasca radioterapi. Dari data yang didapat, dilakukan studi deskriptif dan analisis observasional. Hasil penelitian ditabulasi dan disajikan secara deskriptif dalam bentuk tabel dan diagram. Analisis kesintasan (survival analysis) dengan metode Kaplan Meier. Analisis ini hanya pada pasien yang masih hidup, pasien yang meninggal dan lost of follow up secara otomatis akan tersensor. Kelayakan etik didapatkan dari Komisi Etik untuk penelitian ilmu dasar/klinik di RSUD Dr. Soetomo/Fakultas Kedokteran Universitas Airlangga Surabaya.

\section{HASIL DAN PEMBAHASAN}

Pada penelitian ini didapatkan jumlah pasien baru kanker serviks III-IVA di Poli Onkologi Kandungan RSUD Dr. Soetomo selama tahun 2011-2013 sebanyak 648 pasien. Dari seluruh 648 pasien tersebut, 539 pasien belum mendapat tindakan, meninggal dan mendapat kemoterapi menunggu antrian radioterapi. Selama tahun 2011-2013, didapatkan 109 pasien kanker serviks stadium III-IVA yang mendapat terapi radiasi. Dua puluh tujuh pasien mendapat terapi radiasi langsung, dan 82 pasien menjalani kemoterapi terlebih dulu sambil menunggu antrian radioterapi. Dari 82 pasien tersebut, 5 pasien tidak menyelesaikan radioterapi (drop out) karena pasien menolak tindakan radiasi selanjutnya dan tidak datang evaluasi pasca radioterapi. Sehingga hanya 77 pasien yang memenuhi kriteria inklusi penelitian ini. Protokol penelitian ini dapat dilihat pada gambar 1.

Berdasarkan kelompok stadium menunjukkan sebagian besar pasien dalam stadium IIIB sebesar 91,7\% (594 pasien). Pasien kanker serviks stadium IIIA sebesar 7,4\% (48 pasien) dan stadium IVA sebesar 0,9\% (6 pasien). Pasien kanker serviks stadium III-IVA mempunyai nilai rata-rata usia 51,59 + 8,56 tahun (usia termuda 30 tahun, usia tertua 82 tahun). Berdasarkan kelompok usia, frekuensi tertinggi pada kelompok usia 50-59 tahun dan 40-49 tahun, masing-masing 42,9\% (278 kasus) dan 33,0\% (214 kasus). Karakteristik pasien kanker serviks stadium III-IVA di RSUD Dr.Soetomo tahun 2011-2013 dapat dilihat pada tabel 1.

Pada penelitian ini didapatkan beberapa jenis histopatologi biopsi serviks yaitu squamous cell carcinoma, adenocarcinoma, adenosquamous, small cell carcinoma, clear cell carcinoma dan undifferentiated carcinoma. Histopatologi terbanyak kelompok squa-mous cell carcinoma sebesar 77,2\% (500 pasien), adenocarcinoma sebesar $15,9 \%$ (103 pasien) dan kelompok adenosquamous sebesar 4,0\% (26 pasien). Rentang paritas pasien kanker serviks III-IVA adalah 0-13 dan rata-rata paritas adalah 3,26 dengan simpangan baku 1,923. 
Kebanyakan pasien mempunyai paritas >3 sebesar $33,9 \%$ dan paritas 2 sebesar $27,6 \%$.

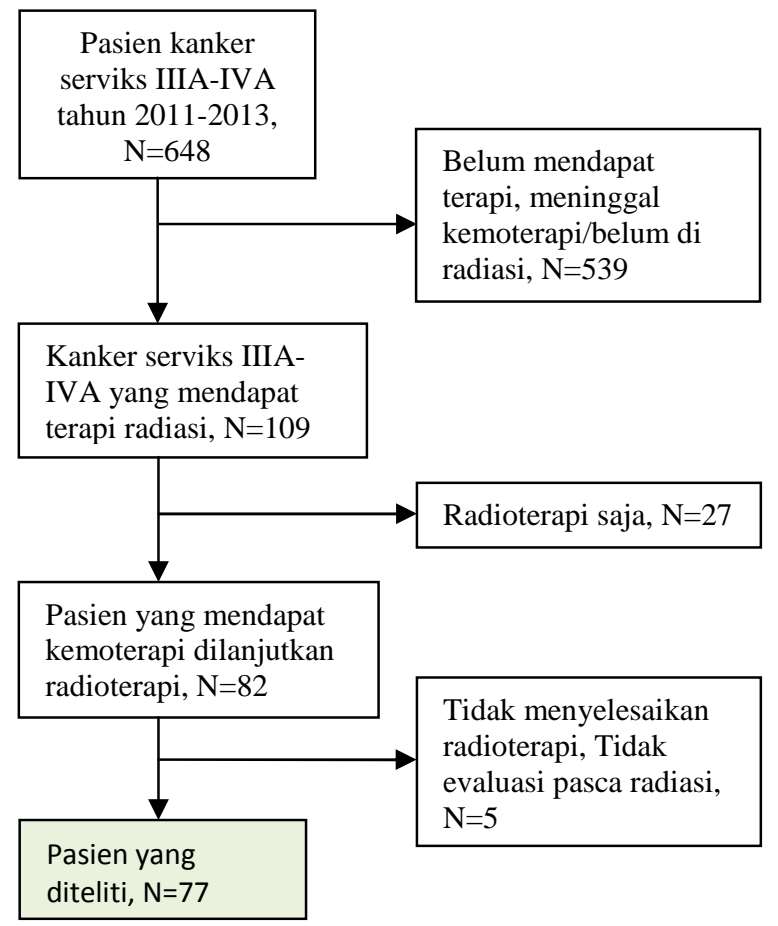

Gambar 1. Protokol subyek peneltian

Tabel 1. Karakteristik pasien kanker serviks stadium IIIIVA di RSUD Dr.Soetomo Tahun 2011-2013 (n:648)

\begin{tabular}{lcc}
\hline Karakteristik & Frekuensi & Persentase \\
\hline Stadium & & \\
III A & 48 & 7,4 \\
III B & 594 & 91,7 \\
IV A & 6 & 0,9 \\
\hline Kelompok usia (tahun) & & \\
30-39 & 42 & 6,5 \\
$40-49$ & 214 & 33,0 \\
$50-59$ & 278 & 42,9 \\
$\geq 60$ & 114 & 17,6 \\
\hline Paritas & & \\
0 & 32 & 4,9 \\
1 & 65 & 10,0 \\
2 & 179 & 27,6 \\
3 & 153 & 23,6 \\
$>3$ & 219 & 33,9 \\
\hline Histopatologi & & \\
Squamous Cell Ca & 500 & 77,2 \\
Adenocarcinoma & 103 & 15,9 \\
Adenosquamous & 26 & 4,0 \\
Jenis lain & 19 & 2,9 \\
\hline Ukuran Tumor & & \\
$\leq 4$ cm & 213 & 32,9 \\
\hline
\end{tabular}

\begin{tabular}{ccc}
\hline$>4 \mathrm{~cm}$ & 322 & 49,7 \\
Tidak diukur & 113 & 17,4 \\
\hline Tatalaksana & & \\
Belum dilakukan & 218 & 33,6 \\
tindakan & 326 & 50,3 \\
Kemoterapi & 77 & 11,9 \\
Kemoterapi- & 27 & 4,2 \\
radioterapi & & \\
Radioterapi & & \\
\hline Kondisi Terakhir & 112 & 17,3 \\
Hidup & 61 & 9,4 \\
Meninggal & 475 & 73,3 \\
Lost of follow up & &
\end{tabular}

Ukuran tumor yang diukur adalah besarnya massa pada serviks melalui pemeriksaan vaginal toucher (VT). Kelompok ukuran tumor $\leq 4 \mathrm{~cm}$ sebesar 32,9\% (213 pasien), kelompok ukuran tumor $>4 \mathrm{~cm}$ sebesar $49,7 \%$ (322 pasien) dan $17,4 \%$ (113 pasien) tidak diukur massa tumor.

Modalitas terapi yang utama pada kanker serviks stadium lanjut (stadium IIB-IVA) adalah radioterapi. Pada penelitian ini, pasien yang langsung mendapat radioterapi hanya sebesar 4,2\% (27 kasus) saja, sementara $11,9 \%$ (77 kasus) harus mendapat kemoterapi terlebih dahulu dan dilanjutkan radioterapi. Sebanyak 50,3\% (326 kasus) masih mendapat kemoterapi saja, dan masih banyak pasien yang belum dilakukan tindakan $(33,6 \%, 218$ kasus). Jadi, pada tahun 20112013 di Poli Onkologi Kandungan RSUD Dr.Soetomo hanya 104 pasien kanker serviks III-IVA yang menjalani terapi radiasi dan telah dilakukan evaluasi klinis pasca radioterapi. Pada pengamatan kami, didapatkan 73,3\% (475 dari 648 pasien) pasien lost of follow up, $17,3 \%$ (112 pasien) masih hidup dan 9,4\% (61 pasien) meninggal.

Tabel 2. Distribusi frekuensi respon terapi pasien kanker serviks III-IVA yang mendapat radioterapi (n:27)

\begin{tabular}{ccc}
\hline Respon terapi & Frekuensi & Persentase \\
\hline Respon komplet & 19 & 70,4 \\
Respon inkomplet & 8 & 29,6 \\
\hline Total & 27 & 100,00 \\
\hline
\end{tabular}

Penilaian respon klinis terhadap radioterapi dilakukan melalui pemeriksaan vaginal toucher (VT). Sebanyak 27 pasien kanker serviks stadium III-IVA mendapat radioterapi saja. Dari 27 pasien tersebut, sebesar 70,4\% (19 dari 27 pasien) dinyatakan respon komplet setelah mendapatkan radioterapi, sedangkan sebesar $29,6 \%$ (8 dari 27 pasien) dinyatakan respon inkomplet terhadap radioterapi (tabel 2). 
Tabel 3. Distribusi frekuensi respon terapi pasien kanker serviks III-IVA yang mendapat kemoterapi dilanjutkan radioterapi (n:77)

\begin{tabular}{ccc}
\hline Respon terapi & Frekuensi & Persentase \\
\hline Respon komplet & 68 & 88,3 \\
Respon inkomplet & 9 & 11,7 \\
\hline Total & 77 & 100,00 \\
\hline
\end{tabular}

Selama tahun 2011-2013 didapatkan jumlah pasien kanker serviks kemoterapi dilanjutkan radioterapi sebesar 77 pasien. Berdasarkan respon terapi didapatkan $88,3 \%$ dinyatakan respon terapi komplet dan $11,7 \%$ dinyatakan respon terapi inkomplet (tabel 3).

Sarana radioterapi di RSUD Dr.Soetomo memiliki keterbatasan alat. Sehingga terapi definitif pasien kanker serviks stadium lanjut sering tertunda. Pada penelitian ini, dilakukan pengamatan mengenai berapa lama pasien kanker serviks stadium III-IVA mendapat radiasi pertama kali dihitung sejak tanggal diagnosis. Didapatkan hasil rata-rata lama antri pasien untuk mendapat radiasi pertama adalah $120,0 \pm 69,0$ hari (waktu terpendek menunggu radiasi adalah 15 hari dan waktu terlama menunggu radiasi adalah 233 hari). Kelompok rentang waktu menunggu radiasi terbanyak adalah pada rentang waktu 5-6 bulan sebesar 42,3\% (44 dari 104 pasien), dan rentang waktu 3-4 bulan sebesar 19,2\% (20 dari 104 pasien) (tabel 4).

Tabel 4. Distribusi frekuensi pasien kanker serviks stadium III-IVA tahun 2011-2013 berdasarkan rentang waktu sejak didiagnosis sampai dilakukan radioterapi pertama (n:104)

\begin{tabular}{ccc}
\hline $\begin{array}{c}\text { Rentang waktu } \\
\text { (bulan) }\end{array}$ & Frekuensi & Persentase \\
\hline$<1$ & 18 & 17,3 \\
$1-2$ & 19 & 18,3 \\
$3-4$ & 20 & 19,2 \\
$5-6$ & 44 & 42,3 \\
$>7$ & 3 & 2,9 \\
\hline Total & 104 & 100,00 \\
\hline
\end{tabular}

Pada penelitian ini, didapatkan 77 pasien yang mendapat kemoterapi dilanjutkan radioterapi. Pasien kanker serviks IIIA sebanyak 8 pasien, dimana 87,5\% (7 pasien) dinyatakan respon terapi komplet dan $12,5 \%$ (1 pasien) dinyatakan respon terapi inkomplet. Pada pasien kanker serviks IIIB yang mendapat kemoterapi dilanjutkan radioterapi sejumlah 69 pasien, didapatkan 88,4\% (61 pasien) dinyatakan respon terapi komplet dan 11,6\% (8 pasien) dinyatakan respon terapi inkomplet. Tidak ada pasien kanker serviks IV-A yang mendapat kemoterapi dilanjutkan radioterapi (tabel 5).
Tabel 5. Tabulasi silang respon terapi pasien kanker serviks III-IVA yang mendapat kemoterapi dilanjutakan radioterapi tahun 2011-2013 berdasarkan stadium (n:77)

\begin{tabular}{cccc}
\hline \multirow{2}{*}{ Stadium } & \multicolumn{2}{c}{ Respon Terapi } & \multirow{2}{*}{ Total } \\
\cline { 2 - 3 } & Komplet & Inkomplet & \\
\hline \multirow{2}{*}{ III A } & 7 & 1 & 8 \\
& $87,5 \%$ & $12,5 \%$ & $100,0 \%$ \\
\multirow{2}{*}{ III B } & 61 & 8 & 69 \\
& $88,4 \%$ & $11,6 \%$ & $100,0 \%$ \\
\hline \multirow{2}{*}{ Total } & 68 & 9 & 77 \\
& $88,3 \%$ & $11,7 \%$ & $100,0 \%$ \\
\hline
\end{tabular}

Pada pasien dengan hasil histopatologi biopsi serviks squamous cell carcinoma, dari 55 pasien, didapatkan $85,5 \%$ (47 pasien) yang mengalami respon terapi komplet dan $14,5 \%$ (8 pasien) yang mengalami respon terapi inkomplet. Pasien dengan histopatologi adenocarcinoma, berjumlah 20 pasien, didapatkan 95,0\% (19 pasien) mengalami respon terapi komplet dan 5,0\% (1 pasien) mengalami respon terapi inkomplet. Didapatkan 1 pasien dengan histopatologi adenosquamous yang mengalami respon terapi komplet (100\%) dan 1 pasien dengan histopatologi jenis lain (small cell carcinoma) yang mengalami respon terapi komplet (tabel 6).

Tabel 6. Tabulasi silang respon radioterapi pasien kanker serviks III-IVA yang mendapat kemoterapi dilanjutkan radioterapi berdasarkan jenis histopatologi (n:77)

\begin{tabular}{cccc}
\hline \multirow{2}{*}{ Histo PA } & \multicolumn{2}{c}{ Respon Terapi } & \multirow{2}{*}{ Total } \\
\cline { 2 - 3 } & Komplet & Inkomplet & \\
\hline \multirow{2}{*}{ SCC } & 47 & 8 & 55 \\
& $85,5 \%$ & $14,5 \%$ & $100,0 \%$ \\
AdenoCa & 19 & 1 & 20 \\
Adenosquamo & $95,0 \%$ & $5,0 \%$ & $100,0 \%$ \\
us & 1 & 0 & 1 \\
Jenis lain & $100,0 \%$ & $0,0 \%$ & $100,0 \%$ \\
& 1 & 0 & 1 \\
Total & $100,0 \%$ & $0,0 \%$ & $100,0 \%$ \\
\hline SCC : Squamous cell carcinoma & $88,3 \%$ & $11,7 \%$ & $100,0 \%$ \\
\hline
\end{tabular}

Berdasarkan Overall Time Treatment (OTT) didapatkan 1 pasien dengan OTT kurang dari atau sama dengan 56 hari yang mengalami respon komplet $(100 \%)$. Pada kelompok OTT lebih besar dari 56 hari didapatkan $88,2 \%$ (67 pasien) yang mengalami respon komplet dan $11,8 \%$ (9 pasien) dengan respon inkomplet (tabel 7). Berdasarkan jenis radiasi eksterna yang diberikan kepada pasien kanker serviks stadium III-IVA yang mendapat kemoterapi dilanjutkan radioterapi terbanyak 
pada kelompok mendapat radiasi eksterna-lapangan dipersempit sebesar 90,9\%, (70 pasien) dan kelompok radiasi eksterna-brakhiterapi sebesar $9,1 \%$ (7 pasien) (tabel 8).

Tabel 7. Tabulasi silang respon radioterapi pasien kanker serviks III-IVA yang mendapat kemoterapi dilanjutkan radioterapi berdasarkan Overall Time Treatment (n:77)

\begin{tabular}{cccc}
\hline Overall Time & \multicolumn{2}{c}{ Respon Terapi } & \multirow{2}{*}{ Total } \\
\cline { 2 - 3 } Treatment & Komplet & Inkomplet & \\
\hline \multirow{2}{*}{$\leq 56$ hari } & 1 & 0 & 8 \\
& $100,0 \%$ & $0,0 \%$ & $100,0 \%$ \\
$>56$ hari & 67 & 9 & 69 \\
& $88,2 \%$ & $11,8 \%$ & $100,0 \%$ \\
\hline \multirow{2}{*}{ Total } & 68 & 9 & 77 \\
& $88,3 \%$ & $11,7 \%$ & $100,0 \%$ \\
\hline
\end{tabular}

Tabel 8. Distribusi frekuensi pasien kanker serviks IIIIVA yang mendapat kemoterapi dilanjutkan radioterapi berdasarkan jenis radiasi eksterna (n:77)

\begin{tabular}{ccc}
\hline Radiasi Eksterna & Frekuensi & Persentase \\
\hline $\mathrm{RE} \pm$ small field & 70 & 90,9 \\
$\mathrm{RE} \pm$ Brakhiterapi & 7 & 9,1 \\
\hline Total & 77 & 100,0 \\
\hline
\end{tabular}

Hasil follow up pada 77 pasien kanker serviks stadium III-IVA didapatkan 64 pasien $(83,1 \%)$ yang masih hidup, 28 pasien sudah menjalani follow up selama 1-2 tahun masih dan 36 pasien dalam follow up $>2$ tahun. Sepuluh pasien $(13,0 \%)$ lost of follow up, 2 pasien dalam waktu kurang dari 1 tahun, 2 pasien 1-2 tahun dan 6 pasien $>2$ tahun. Pasien meninggal 3 pasien (3,9\%), 2 meninggal dalam waktu 1-2 tahun dan 1 pasien meninggal antara $>2$ tahun. Persangkaan penyebab kematian pada 3 pasien tersebut kesemuanya disebabkan syok septik.

Pada analisis survival dengan metode Kaplan-Meier, didapatkan estimasi median survival pada kelompok stadium IIIA sebesar 33 bulan dan estimasi median survival pada kelompok stadium IIIB sebesar 23 bulan dengan median survival semua kelompok 25 bulan. Pada kelompok stadium IIIA didapatkan 2-YSR sebesar $86 \%$ sedangkan 3-YSR sebesar 34\%. Pada kelompok stadium IIIB didapatkan 2-YSR sebesar 47\% dan 3YSR sebesar $25 \%$. Dari hasil analisis statistik, perbedaan median survival antara stadium IIIA dan IIIB tidak bermakna secara statistik $(\mathrm{p}=0,507)$.

\section{Karakteristik Demografi Pasien Kanker Serviks III-IVA di RSUD Dr. Soetomo Tahun 20 I I-20 I 3}

Pada penelitian ini, didapatkan pasien baru kanker serviks III-IVA menurut data Poli Onkologi Kandungan sebanyak 648 pasien. Pada penelitian ini, didapatkan pasien kanker serviks stadium IIIA sebanyak 48 pasien, IIIB sebanyak 594 pasien dan stadium IVA sebanyak 6 pasien. Usia rata-rata pasien kanker serviks III-IVA pada penelitian ini adalah 51,59 \pm 8,56 tahun (usia termuda adalah 30 tahun, dan usia tertua 82 tahun). Pada penelitian di Rumah Sakit Dr. Cipto Mangunkusumo Jakarta tahun 2010 didapatkan usia rata-rata pasien kanker serviks adalah 51,42 \pm 9,64 tahun. $^{7}$ Penelitian multicenter pada pasien kanker serviks IIBIIIB yang melibatkan beberapa negara di Asia Timur dan Asia Tenggara, termasuk Indonesia, melaporkan usia rata-rata pasien kanker serviks adalah 51 tahun (rentang usia 28-70 tahun). ${ }^{8}$

Ditinjau dari kelompok usia, didapatkan kelompok usia terbanyak pada usia 50-59 tahun sebanyak 278 pasien (42,9\%) dan kelompok usia 40-49 tahun sebanyak 214 pasien $(33,0 \%)$. Hal ini sesuai dengan penelitian sebelumnya yang menyatakan rata-rata usia pasien 4752,2 tahun. ${ }^{9}$ Usia pasien kanker serviks antara 40-59 tahun. ${ }^{10}$

Berdasarkan paritas, nilai rata-rata pasien pada penelitian ini adalah 3,26 \pm 1,923 (rentang paritas pada penelitian ini adalah 0-13). Kebanyakan pasien mempunyai paritas 2 sebesar 27,6\%. Menurut penelitian oleh Parazzini, paritas terbanyak kanker serviks adalah 2 sebesar $27 \%$. Didapatkan peningkatan resiko kanker serviks sesuai dengan bertambahnya paritas dengan relative risk (RR) 4,39. ${ }^{11}$ Dua jenis histopatologi yang dominan pada kanker serviks adalah squamous cell carcinoma (SCC) dan adenocarcinoma. SCC merupakan jenis histopatologi terbanyak mencapai $85 \%$, sedangkan adenocarcinoma mencapai $10-15 \%$ kasus. ${ }^{10}$ Pada penelitian ini, kelompok SCC sebanyak 500 pasien (77,2\%) sedangkan kelompok adenocarcinoma mencapai 103 pasien $(15,9 \%)$. Penelitian oleh Sakata di Jepang didapatkan jenis SCC sebesar 94,2\% dan adenocarcinoma sebesar $4,9 \%{ }^{12}$

Kanker serviks stadium lanjut (stadium IIB-IVA) sesuai standar FIGO mendapat terapi kemoterapi konkomitan radioterapi. Kebijakan divisi ginekologi onkologi RSUD Dr.Soetomo, pasien kanker serviks stadium III-IVA mendapat tatalaksana kemoterapi dilanjutkan radioterapi. Hal ini karena keterbatasan sarana radioterapi. Pada penelitian ini, didapatkan beberapa jenis modalitas terapi yang dikerjakan pada pasien kanker serviks stadium III-IVA antara lain radioterapi saja $27(4,2 \%)$, kemoterapi dilanjutkan radioterapi 77 pasien $(11,9 \%)$, 
kemoterapi saja $326(50,3 \%)$ dan $218(33,6 \%)$ belum dilakukan tindakan.

Selama tahun 2011 sampai 2013 di RSUD Dr.Soetomo didapatkan 104 pasien yang menjalani radioterapi dan telah dilakukan evaluasi pasca radioterapi. Berdasarkan respon terapi, didapatkan 87 pasien $(83,7 \%)$ dinilai respon komplet pasca radioterapi dan 17 pasien $(16,3 \%)$ dinilai respon inkomplet untuk semua kelompok.

\section{Respon Terapi Pasien Kanker Serviks III-IVA Yang Mendapat Kemoterapi Dilanjutkan Radioterapi Berdasarkan Stadium}

Selama tahun 2011 sampai 2013 didapatkan 77 pasien yang mendapat kemoterapi dilanjutkan radioterapi, dilihat berdasarkan stadium didapatkan 8 pasien stadium IIIA dan 69 pasien stadium IIIB. Tidak ada pasien kanker serviks stadium IVA yang mendapat kemoterapi dilanjutkan radioterapi. Dari 6 pasien kanker serviks IVA didapatkan 4 pasien lost of follow up dan 2 pasien meninggal. Pada pasien kanker serviks IIIA didapatkan 87,5\% (7 pasien) dinyatakan respon terapi komplet dan $12,5 \%$ (1 pasien) dinyatakan respon terapi inkomplet. Sedangkan pada pasien kanker serviks IIIB yang mendapat kemoterapi dilanjutkan radioterapi sejumlah 69 pasien, didapatkan $88,4 \%$ (61 pasien) dinyatakan respon terapi komplet dan $11,6 \%$ (8 pasien) dinyatakan respon terapi inkomplet. Untuk semua kelompok stadium, didapatkan respon komplet sebesar 88,3\% dan respon terapi inkomplet sebesar $11,7 \%$.

Penilaian respon terapi pasien kanker serviks pasca terapi radiasi di RSUD Dr.Soetomo dengan cara pemeriksaan fisik vaginal toucher (VT) yang dilakukan kurang lebih 14 hari pasca pemberian radiasi terakhir. Hasil ini lebih tinggi bila dibandingkan pada penelitian yang dilakukan oleh Wong tahun 1999. Penelitian tersebut membandingkan efektifitas pemberian radiasi saja dengan kemoradiasi konkomitan pada pasien kanker serviks stadium IIB-IVA. Penelitian tersebut didapatkan pasien yang mendapat kemoradiasi konkomitan dengan hasil repon komplet didapatkan pada 78 dari 110 pasien $(70,9 \%) .{ }^{13}$ Penelitian oleh Negi tahun 2010 pada 102 pasien kanker serviks stadium lanjut dilaporkan $77,4 \%$ pasien mengalami respon komplet pasca pemberian kemoradiasi konkomitan. ${ }^{14}$

\section{Respon Terapi Pasien Kanker Serviks III-IVA Yang Mendapat Kemoterapi Dilanjutkan Radioterapi Berdasarkan Jenis Histopatologi}

Dari pengamatan terhadap 77 pasien yang mendapat kemoterapi dilanjutkan radioterapi didapatkan 4 jenis histopatologi biopsi. Keempat jenis terseburt adalah squamous cell carcinoma, adenocarcinoma, adeno- squamous, dan small cell carcinoma. Pada 55 pasien kanker serviks III-IVA dengan hasil histopatologi biopsi serviks squamous cell carcinoma, didapatkan 85,5\% (47 pasien) yang mengalami respon terapi komplet dan $14,5 \%$ (8 pasien) yang mengalami respon terapi inkomplet. Pasien dengan histopatologi adenocarcinoma, berjumlah 20 pasien, didapatkan 95,0\% (19 pasien) mengalami respon terapi komplet dan 5,0\% (1 pasien) mengalami respon terapi inkomplet. Didapatkan 1 pasien dengan histopatologi adenosquamous yang dinyatakan respon terapi komplet $(100 \%)$ dan 1 pasien dengan histopatologi small cell carcinoma yang dinyatakan respon terapi komplet.

Beberapa penelitian yang menghubungkan antara jenis histopatologi dan luaran pada pasien kanker serviks menghasilkan kesimpulan yang hingga saat ini masih kontroversi. Penelitian oleh Yoshida di Jepang menyebutkan bahwa pasien kanker serviks stadium II dan III dengan histopatologi adenocarcinoma yang dilakukan radioterapi, didapatkan rata-rata kesintasan hidup dalam 5 tahun sebesar $20-40 \%$ lebih rendah daripada squamous cell carcinoma. ${ }^{15}$

Penelitian oleh Sura pada tahun 2008 menyimpulkan dalam penelitian-nya bahwa rata-rata kesintasan pasien kanker serviks stadium lanjut dengan histopatologi adenocarcinoma lebih rendah 10 bulan dibandingkan dengan histo-patologi squamous cell carcinoma. Hal ini dikaitkan dengan sensitifitas sel kanker terhadap terapi radiasi. $^{16}$

Penelitian oleh Lee tahun 2006 menyimpulkan bahwa tidak ada perbedaan yang bermakna pada disease free survival selama 48 bulan antara pasien kanker serviks dengan histopatologi squamous cell carcinoma dengan adenocarcinoma. Pada kelompok histopatologi squamous cell carcinoma sebesar $89,8 \%$ sedangkan pada kelompok histopatologi adenocarcinoma sebesar 83,6\% ( $\mathrm{p}=$ tidak signifikan). ${ }^{17}$ Penelitian oleh Monk dan Tewari menyatakan tidak ada perbedaan angka kesembuhan antara adenocarcinoma dan squamous cell carcinoma. ${ }^{18}$

Pada penelitian yang dilakukan di Thailand dengan sampel yang dikumpulkan selama 15 tahun, didapatkan angka kesintasan hidup 5 tahun yang tidak berbeda antara kedua kelompok histopatologi. Dikatakan luaran pasien jenis adenocarcinoma dengan kemoradiasi konkomitan juga tidak berbeda secara statistik dibandingkan jenis squamous cell carcinoma.$^{19}$ Penelitian yang dilakukan sebelumnya di RSUD Dr.Soetomo juga menyimpulkan bahwa tidak ada perbedaan survival antara kedua jenis histopatologi. ${ }^{5}$ 


\section{Respon Terapi Pasien Kanker Serviks III-IVA Yang Mendapat Kemoterapi Dilanjutkan Radioterapi Berdasarkan Overall Time Treatment (OTT)}

Dalam radioterapi dikenal istilah Overall Time Treatment (OTT) yaitu lamanya masa terapi radiasi lengkap yang diberikan kepada seorang pasien, yakni mulai hari pertama pemberian radiasi eksterna hingga hari terakhir pemberian brakhiterapi atau radiasi eksterna lapangan kecil (small field). Rentang Overall Time Treatment (OTT) pada penelitian ini adalah 56-106 hari (median 76 hari). Pada penelitian ini, OTT dibagi menjadi 2 kelompok yaitu kelompok dengan OTT $<56$ hari sebesar 1,3\% (1 dari 77 pasien) dan kelompok dengan OTT > 56 hari sebesar 98,7\% (76 dari 77 pasien).

The American Brachytherapy Society merekomendasikan bahwa OTT pada pasien kanker serviks seharusnya 8 minggu atau 56 hari. $^{20}$ Beberapa penelitian menyimpulkan bahwa OTT merupakan salah satu faktor prognosis yang signifikan berpengaruh pada pasien kanker serviks yang mendapat terapi radiasi saja. OTT berpengaruh pada kemampuan local control pada terapi kanker serviks. ${ }^{21}$ Penelitian oleh Girinsky melaporkan penurunan angka local control dan survival pada pasien kanker serviks ketika lama terapi yang dijalani lebih dari 56 hari. Girinsky mengamati terjadinya penurunan $1,1 \%$ local control tiap harinya ketika lama pengobatan memanjang lebih dari 56 hari. $^{22}$

Pada penelitian ini, ditemukan hanya 1 pasien yang mempunyai OTT < 56 hari dan 76 pasien yang lain mempunyai OTT > 56 hari. Pemanjangan OTT terjadi karena pada saat pasien menjalani radioterapi mengalami gangguan hematologi (anemia, leukopenia dan trombositopenia) sehingga terjadi penundaan pemberian radioterapi lanjutan.

Di RSUD Dr.Soetomo masih didapatkan kendala untuk melakukan radioterapi sesuai jadwal. Terdapat kekurangan alat jika dibandingkan dengan banyaknya pasien yang harus dilayani. Akibatnya, sebagian besar pasien harus antri sebelum dilakukan radioterapi. Kami dapatkan sebagian pasien (44 dari 104 pasien atau sebesar $42,3 \%$ ) harus menunggu selama rentang waktu 5-6 bulan sebelum mendapatkan radioterapi. Bahkan, didapatkan 3 pasien $(2,9 \%)$ mendapatkan radioterapi setelah menunggu selama lebih 7 bulan.

Dari pengamatan kami ini, didapatkan antrian yang lama bagi pasien kanker serviks untuk mendapat radioterapi berhubungan dengan kejadian kerusakan alat radioterapi di RSUD Dr.Soetomo selama tahun 2011 sampai 2013. Menurut data SMF/Instalasi Radioterapi
RSUD Dr. Soetomo, pada tahun 2011 breakdown time alat radioterapi hanya $0,8-3,9 \%$ pertahun, pada tahun 2012 breakdown time sebesar 11,6-18,2\% dan tambah besar pada tahun 2013 24,1-56,5\%. Semakin besar breakdown time alat radioterapi tersebut menyebabkan terganggunya pelayanan radioterapi pada semua pasien kanker dan antrian radiasi bertambah banyak.

Kebijakan Divisi Ginekologi Onkologi RSUD Dr. Soetomo untuk terapi pasien kanker serviks stadium lanjut (locally advanced) adalah pemberian kemoterapi sebelum radioterapi. Sehingga selama waktu menunggu radioterapi ini, pasien akan mendapatkan kemoterapi cisplatin 3 mingguan dengan dosis $50 \mathrm{mg} / \mathrm{m} 2$. Adanya jeda waktu dalam menunggu jadwal radioterapi pada sebagian besar pasien mungkin berpengaruh terhadap survival pasien. Repopulasi sel-sel kanker akan berjalan sampai terapi utama berupa radiasi dilaksanakan. Repopulasi sel-sel yang resisten terhadap pengobatan akan berpengaruh terhadap survival secara langsung. ${ }^{23}$

\section{Survival Pasien Kanker Serviks Stadium III-IVA Yang Mendapat Kemoterapi Dilanjutkan Radioterapi}

Hasil follow up pada 77 pasien dalam penelitian ini didapatkan 2 (dua) kejadian efek samping lanjut pasca radioterapi yaitu terjadi gangguan colitis kronis dan ditemukan inkontinensia urine pasca radioterapi. Pada penelitian ini, pengukuran survival pasien kanker serviks yang mendapat kemoterapi dilanjutkan radioterapi ditemukan kendala berupa rekam medis yang kurang lengkap. Selain itu peneliti mengalami kendala dengan banyaknya pasien lost of follow up yang mencapai 12,98\%. Dalam life table, didapatkan 64 pasien masih hidup saat penelitian ini berjalan. Pasien terbanyak di follow up selama lebih dari 2 tahun sejumlah 36 pasien. Sedangkan pasien yang hidup dan di follow up 1-2 tahun berjumlah 28 pasien. Pada penelitian ini, didapatkan 3 pasien yang meninggal dengan persangkaan penyebab kematian syok septik.

Pada penelitian ini dilakukan analisis survival dengan menggunakan rumus Kaplan-Meier, didapatkan pada pasien stadium IIIA, median survival sebesar 33 bulan (artinya $50 \%$ pasien stadium IIIA meninggal dalam waktu 33 bulan), sedangkan pada pasien stadium IIIB didapatkan median survival sebesar 23 bulan (artinya $50 \%$ pasien stadium IIIB meninggal dalam waktu 23 bulan) dengan median survival seluruh pasien adalah 25 bulan. Pada kelompok stadium IIIA didapatkan 2-years survival rate sebesar $86 \%$ sedangkan 3-years survival rate sebesar $34 \%$. Pada kelompok stadium IIIB didapatkan 2-years survival rate sebesar $47 \%$ dan 3-years survival rate sebesar $25 \%$. Meskipun terdapat perbedaan 10 bulan antara kedua kelompok berdasarkan 
stadium, secara statistik tidak didapatkan perbedaan bermakna $(p=0,507)$. Hal ini bisa disimpulkan bahwa secara statistik, estimasi survival antara pasien stadium IIIA dan stadium IIIB tidak berbeda.

Penelitian oleh Kumar tahun 1998 terhadap 184 pasien kanker serviks IIB-IVA dilaporkan bahwa median survival pasien kanker serviks stadium IIB-IVA yang mendapat kemo-radiasi sebesar 34 bulan. ${ }^{24}$ Penelitian oleh Sardi tahun 1996 pada 54 pasien kanker serviks IIIB yang mendapat konkomitant kemoradiasi didapatkan 3-years survival rates sebesar 53\%. ${ }^{25}$ Hasil penelitian oleh Sardi berbeda dengan penelitian kami mengenai 3-years survival rates dimungkinkan karena adanya perbedaan prosedur pemberian kemoterapi dan radioterapi.

\section{SIMPULAN}

Jumlah pasien kanker serviks stadium III-IVA yang mendapat kemoterapi dilanjutkan radioterapi selama tahun 2011-2013 sebanyak 77 pasien (stadium IIIA 8 pasien, stadium IIIB 69 pasien). Berdasarkan respon terapi didapatkan respon terapi komplet sebesar 88,3\% dan respon terapi inkomplet sebesar $11,7 \%$. Pada analisis survival didapatkan 2-years survival rates dan 3- years survival rates stadium IIIA sebesar $86 \%$ dan $34 \%$. Stadium IIIB didapatkan 2-years survival rates dan 3- years survival rates sebesar $47 \%$ dan $25 \%$.

\section{DAFTAR PUSTAKA}

1. Aziz MF. Gynecological cancer in Indonesia. Journal gynecology oncology. 2009;20(1):8-10.

2. Ferlay J, Soerjomataram I, Ervik M, Dikshit R, Eser S, Mathers C, Rebelo M, Parkin DM, Forman D, Bray F. GLOBOCAN 2012 v1.0, Cancer Incidence and Mortality Worldwide: IARC Cancer Base No. 11 [Internet]. Lyon, France: International Agency for Research on Cancer. Available from http://globocan.iarc.fr. 2013.

3. Andrijono. Kanker serviks uteri. Dalam Sinopsis Kanker Ginekologi. Edisi ke-3. Jakarta: Pustaka Spirit; 2009. p. 59-125.

4. Eifel PJ, Jhingran A, Brown J, Levenback C, Thames H. Time course and outcome of central recurrence after radiation therapy for carcinoma of the cervix. Int J gynecol Cancer. 2006;16:1106-11.

5. Achmadi, Tjokroprawiro BA, Suhatno. Karakteristik Pasien Kanker Serviks 2006-2010 di RSUD dr. Soetomo, Departemen/SMF Obstetri Ginekologi Fakultas Kedokteran Universitas Airlangga. Laporan Hasil Penelitian. 2011. p. 32-69.
6. Nakano $\mathrm{T}$, Kato $\mathrm{S}$, Ohno $\mathrm{T}$, Tsuji $\mathrm{H}$, Sato $\mathrm{S}$, Fukuhisa K, Arai T. Long-Term Results of HighDose Rate Intracavitary Brachytherapy for Squamous cell carcinoma of the Uterine Cervix. American Cancer Society. 2005;103(1):92-101.

7. Anggraeni TD, Nuranna L. Distribution of Age, Stage, and Histopathology of Cervical Cancer: A Retrospective Study on Patients at Dr. Cipto Mangunkusumo Hospital Jakarta 2006-2010. Indones J Obstet Gynecol. 2011;35:21-4.

8. Kato S, Ohno T, Thephamongkhol K, Chansilpa Y, Cao J, Xu X, Devi CR, Swee TT, Calaguas MJ, de Los Reyes RH, Cho CK, Dung TA, Supriana N, Erawati D, Mizuno H, Nakano T, Tsujii H. Longterm follow-up results of a multi-institutional phase 2 study of concurrent chemoradiation therapy for locally advanced cervical cancer in east and southeast Asia. Int J Radiat Oncol Biol Phys. 2013;87(1):100-5.

9. Souhami L. Chemoradiation in Locally advanced cervix cancer: a metaanalysis. Int J Clin OncoL. 2011;14(3):233-41.

10. Schorge JO, et al. Cervical Cancer. In: William Gynecology. 1st Ed. USA: McGraw Hill; 2008. p 646-63.

11. Parazzini F, La Vecchia C, Negri E, Cecchetti G, Fedele L. Reproductive factors and the risk of invasive and intraepithelial cervical neoplasia. British Journal of Cancer. 1989;59(5):805-9.

12. Sakata K, Sakurai H, Suzuji Y, Kato S, Ohno T, Tita T, Kataoka M, Eiichi T, Kaneyasu Y, Uno T, Harima Y, Nakano T. Result of concomitant chemoradiation for cervical cancer using high dose rate intracavitary brachytherapy: Study of JRSOG (Japan Oncology Study Group). Acta Oncol. 2008;47:434-41.

13. Wong LC, Choo YC, Choy D, et al. Long-term follow-up of potentiation of radiotherapy by cisplatinum in advanced cervical cancer. Gynecol Oncol. 1989;35:159-63.

14. Negi RR, Gupta M, Kumar M, Gupta M.K, Seam $\mathrm{R}$, Rastogi M. Concurrent chemoradiation in locally advanced carcinoma cervix patients. J Cancer Res Ther. 2010;6:159-66.

15. Yoshida Y, Sato S, Okamura C, Nishino Y, Yajima A. Evaluating the accuracy of uterine cancer screening with the regional cancer registration system. Acta Cytol. 1991;45:157-62.

16. Sura S, Olshelski M, Rineer J. Effect of histology on survival for patients with invasive nonmetastatic cervical cancer: review of the SEER database. Int J Clin Oncol. 2008;5(2):201-6.

17. Lee JS, Sheets EE, Wenham RM, Duska LR, Coleman RL, Miller DSl. Stage IIB-IV cervical adenocarcinoma: prognostic factors and survival. Gynecol Oncol. 2006;84:115-9. 
18. Monk BJ, Tewari KS. Invasive cervical cancer, in Clinical Gynecologic Oncology (editor Creasman WT dan DiSaia PJ). 7th Eds. USA: Mosby Elsevier; 2007. p. 55-124.

19. Rittiluechai K, Buranawit K, Tanapat Y. The treatment outcome of adenocarcinoma of uterine cervix at Phramongkutklao Hospital. J Med Assoc Thai. 2010;93(6):13-21.

20. Nag S, Erickson B, Thomadsen B, Orton C, Demanes JD, Petereit D. The American Brachytherapy Society recommendations for high dose rate brachytherapy for carcinoma of the cervix. Int $\mathrm{J}$ Radiat Oncol Biol Phys. 2000;48:201-11.

21. Fyles A, Keane TJ, Barton M, Simm J. The effect of treatment duration in the local control of cervix cancer. Radiother Oncol. 1992;25:273-9.

22. Girinsky T, Rey A, Roche B, Haie C, Gerbaulet A, Randrianarivvello $\mathrm{H}$. Overall Time Treatment in advanced Cervical Carcinomas: a critical parameter in treatment outcome. Int J Radiat Oncol Biol Phys. 1993;27:1051-6.

23. Gonzales MA, Lucia GC, Carballo N, Garcia JF, Lapuente F, Rojo A. The current role of neoadjuvant chemoterapy in the management of cervical carcinoma. Gynecol Oncol. 2008;110:3640.

24. Kumar L, Kaushal R, Nandy M. Chemotherapy followed by radiotherapy versus radiotherapy alone in locally advanced cervical cancer: a randomized study. Gynecol Oncol. 1998:54:307-15.

25. Sardi J, Giaroli A, Sananes C. Randomized trial with neoadjuvant chemotherapy in stage $\mathrm{IIIb}$ squamous carcinoma cervix uteri: an unexpected therapeutic management. Int $\mathbf{J}$ Gynecol Cancer. 1996;6:85-93. 